\title{
Long-Term Relationship between Inflation and Public Sector Deficit in the Turkish Economy and its Macroeconomic Implications (1975-2014)
}

\author{
AtillaGökçe, UmutÇakmak* \\ Gazi University, Ankara, Turkey \\ atilla@gazi.edu.tr, ucakmak@gazi.edu.tr
}

\begin{abstract}
The process of deterioration in the fundamentals, in particular those related to inflation and the public sector deficits, that had started in the 1980's have accelerated in the 1990's. Meanwhile two way causative relations seem to have appeared between the fluctuations of some fundamentals. In this context, this paper examines the long term relationship between inflation and the public sector deficit and provides an analysis of the macro dynamics that derive from this relationship. Following a summary of the theoretical literature on the relationship between inflation and the public sector deficit, the behavior of these two variables in the 1975-2014 periods are delineated and an analysis of their relationship to some selected macro-variables is presented. The most important result of this article is that high and chronic inflation rates are one of the responsible of deterioration which appeared on the main economic variables particularly in the public sector balance. Similarly, in the 2000's, on the basis of positive developments in the public balance lies in falling inflation rates quickly and permanently.
\end{abstract}

Keywords: Inflation, Public Sector Deficit, Johansen Cointegration, VECM, Granger Causality

\section{Introduction}

The fact that the regional international integrations started to speed after the 1960s, that the effect of the cold war decreased and that the information age was born, caused the concept of industrialization which was under the supervision and leadership of the states to slow down. The foreign exchange bottle-neck caused by the oil crisis and by the increase of these effects compelled many countries, including Turkey, to make an outward oriented industrialization strategy (Türkkan, 1998). Until the 1980s, until the period in which the Turkish economy showed all the properties of the self-contained economy, the basis of the development and industrialization policies were the import substitution industrialization strategy. In the period of 1970-1977, in which the import substitution was tried to be developed, the increase in oil prices (which is an important industrial input) and the rapid growth in import despite this increase, took the current account deficit (CAD) to an unsustainable level. In addition to this, the fact that the increase in oil prices continued until 1979, caused further increase in shortage of foreign exchange, production downturn and scarcity of goods. It also laid the foundation for high and persistent inflation which will affect the Turkish economy negatively for 30 years (Tokgöz, 1998).All these negative developments have pushed the Turkish economy into a severe economic crisis which started in 1978. The crisis period of 1978-1980 was a turning point in terms of industrialization and economic policies. In order to overcome the economic crisis, 24 January decisions which were put into effect in the January of 1980 revealed that export-based growth model under the free market conditions would be followed in the long term industrialization process.

Adopting an outward-oriented market economy after 1980, the Turkish economy managed to decrease the inflation levels which were close to $100 \%$ in 1980 in the following three years. ${ }^{1}$ The success of decrease in inflation is due to the considerable decrease in real wages and in non-manufacturing terms (agriculturetrade) by the 24 January decisions in other words, to the suppressed domestic demand by the income policies. In addition to this, high inflation policy played an important role in suppressing the internal demand. However, starting from 1984, the inflation which was controlled to a large extension the beginning of the 1980shad the tendency to increase again due to rapid monetary expansion and the increase in non-wage costs (Erçel, 2001). This new trend in inflation rates which started after 1984, continued during 1990s in

\footnotetext{
1 The inflation rates in 1981, 1982, and 1983 were $34 \%, 27 \%$ and $28 \%$ respectively. Source: www.tcmb.gov.tr
} 
which basic macroeconmic indicators (fundamentals) were deterioted considerably and the inflation turned into a high and persistent phase but not into a hyperinflation one. The inflationist process which gained speed in the middle of 1980 s caused both the nominal interest rates to increase and also the quick currency adjustments to gain a continuous form in order to protect the international competitive power. The uncertainty caused by both the high nominal interests and the inflationist environment caused a considerable recession in industrial investments namely the private sector investments when compared to 1970s. (Erçel, 2001). In decrease of private sector investments, public saving deficits which had the tendency to increase from the middle of the 1980s and the withdrawal of the private sector funds by the public with high borrowing interest rates to finance these deficits, were also effective (Crowding-OutEffects). From the second half of the 1980s, the basic macroeconomic indicators which had the tendency to deteriote quickly and the growth rates $^{2}$ which were about to stop, leaded the Turkish economy to engage in different political pursuits. In 1989, with the decision no $32^{3}$, the restrictions over foreign exchange controls and capital movements were removed. Therefore, the foreign trade liberalization which started after 1980 was followed by financial liberalization. Among the most important reasons of financial liberalization, the following can be enumerated: To make the Turkish economy closes these deficits by leaning towards foreign sources and funds and to make it continue the growth dynamism which it has captured after 1983.4

Following the opening of the capital account, the expectation that there will be a significant increase in foreign capital inflows, that the high speed of growth -which was reached before- would be sustained owing to these capital inflows and that the increasing public deficit would be overcomed by the foreign sources and funds, were accepted in general by the economic administration. However, the expected results were not fully reached. There was a rapid increase in foreign capital inflow; however these increases were not continued in medium and long terms. They were carried out in short term capital flows rather than long termed foreign investments. Similarly, following the opening of capital account, even though a high increase in growth of $9.4 \%$ was captured, no stable rates of growth could achieve during 1990s. ${ }^{5}$ It must be importantly emphasized that not only expected results were not achieved through financial liberalization but also the deterioration which stared in the middle of 1980s in basic macroeconomic indicators, namely the inflation and public saving deficit, continued increasingly in the 1990s. Because it was the foregone result that financial liberalization process which was started without making the banking system acquire a healthy structure, without creating a mechanism to supervise $i^{6}{ }^{6}$, without dragging down the high and persistent inflation, without ensuring the budget discipline and without making the structural reforms, would create a range of negative impacts. Short term capital inflows which increased with the liberalization of capital inflows helped to finance the increased public and foreign trade deficits. However, as the short term capital inflows were related to the expectations that the high real interest rates and real foreign currencies would not change, this caused the high interest rates to lower speed. In addition to this, the fact that the increasing short term capital inflows cause monetary expansion, made an extra pressure on inflationist expectations.

The budget deficit and the current account deficit which reached unsustainable levels under the high and persistent inflation were the major factors which caused two important crises of 1994 and 2001. In the crisis of 1994 the Turkish economy shrank by $-6.1 \%$. Whereas in 2001 it shrank by $-9.5 \%$ in which the budget deficit reached its highest level. It must be underlined that the crisis of 2001 was the deepest crisis which has Turkish economy faced throughout the republican history. After the crisis of 2001 which the Turkish economy have passed through, the targets of the public finance were redetermined by the "Program for

${ }^{2}$ Between 1981-1987, average growth rate was $5.7 \%$, the same ratio was $1.4 \%$ and $1.6 \%$ in 1988 and 1989 respectively. Source: www.tcmb.gov.tr

3 The Turkish Lira became convertible by the Decision No.32 for "Protecting the Value of Turkish Currency" which entered into force on 11 August 1989 after being promulgated in the Official Gazette.

4 In the basis of the liberalization movement which started under the leadership of TurgutÖzal, it can be said that the idea of "Considering the liberalization policies as the salvation formulas" played also a role (Çakman-Çakmak, 2003:30).

5The growth rate which was 9.4\% in 1990 declined to $0 \%$ in 1991 and put the Turkish economy into recession. The Turkish economy which grew respectively by $6.4 \%$ and $8.1 \%$ in 1992 and 1993 , shrank by $-6.1 \%$ in 1994 . The average growth rate of 1995-96-97 was 7.7\%. However, due to the Russian crisis of 1998, the growth rate of 1998 declined to $3.9 \%$. As result of the earthquake disaster of August 1999, the growth rate of 1999 declined ti $-6.1 \%$. So the Turkish economy couldn't capture a consistent growth trend in 1990s. Source: www.tcmb.gov.tr

${ }^{6}$ Banking Regulation and Supervision Agency (BRSA) was established in 1999 in Turkey. 
Transition to a Strong Economy" announced on 15 April 2001.The main target of the Program for Transition to a Strong Economy was to eliminate the public deficit dynamic which reached to a unsustainable level and decrease the Turkish economy's need for external help. The main condition to reach that long term basic target is to establish the macroeconomic balances. The tight monetary and fiscal policy applied after the program for Transition to a Strong Economy managed to stop the inertia of high and persistent inflation. The double -digit inflation which had been continuing since 25 years decreased to $9.4 \%$ in 2004 . The decrease in inflation continued relatively after 2004 and was about 7.2\% in average between 2004-2014. ${ }^{7}$ In parallel to the decrease in inflation, the budget deficit decreased considerably and the budget deficit/GDP ratio was below the Maastricht Criteria of 3\% between 2004-2013 (except 2009-2010).

The main purpose of this article is an analysis of the interaction of the high and persistent inflation faced by the Turkish Economy with the basic macroeconomic indicators mainly the public sector balance and the disturbances which it has caused on these indicators. The deterioration of budget balance due to rising interest rate in the wake of the high inflation that became chronic in post 1980 period of Turkish economy and particularly development of a mutual relationship between the budget deficit and inflation in the 1990s are the basic topics analyzed in the article. Similarly, on the basis of improvements in budget deficit and public balance of Turkish economy in 2000s, the impact of the rapidly decreasing inflation rates has also been analyzed in the article. The relationship between inflation and the budget deficit were tested with econometric analysis and interpretations on this topic were intended to be strengthened. Within this context, following the introduction part the theoretical framework is summarized in the second part. In the third part, empirical methods are applied to question long term dynamic relation between the inflation, interest payments and budget balance. The causality relationship between these macroeconomic indicators is tested with VECM. In the fourth final part, the results achieved from the article are discussed while giving an analysis.

Theoretical Framework: Dynamics of Inflation and the Relation between the Public Balance and the Inflation: Classical economists do not have a tolerance for the state's intervention on the economy. They want that the state serve only for defense, diplomacy and public order. According to them, economy finds it balance through price mechanism. So, in the classical system, in case where the activity field of the state is limited, the state budget have to be balanced and have to be as small as possible annually. Any increase in budget spending, will deteriorate the budget balance and any calling on additional taxes to overcome the deficit creates negative impact on investments, savings and labor supply. So by this way, the neutrality of the state will be damaged and the state intervention on the economy will increase. On the other hand, if the state leans towards debt instead of taxation, the interests increase owing to the fact that the state is a competitor to the private sector in loan able funds and the private firms will be excluded from the funds market. In addition to this, classical economists lean towards debts only in state of emergences and in great public works (Yllmaz, 2012). According to the classical economy theory which favors the balanced budget policy, the reason of inflation is expressed by the Quantity Theory created by Fisher (1911). $M$ denotes monetary base, Vdenotes velocity of circulation of money, Pdenotes general level of prices, and Tdenotes volume of trade. The equation is expressed as follows:M.V =P.T In the equation, assuming that the $V$ and Tare constant, there is a correlation between the money supply and general level of prices in the same direction and in the same ratio (Fisher, 1911).

Keynes and the Keynesians disregarded the quantity theory of money developed by the classical economists and they paid secondary importance to the money and monetary institutions in macroeconomic processes. With the Keynesian economy, budget balance concept, which was given importance by the classical economy, started losing its importance and instead "economic balance" concept came into prominence. In addition to this, the Keynesian economists defended that following a budget policy in line with the economic conjuncture is important (Aktan, 2002). John Maynard Keynes claimed that the Great Depression of 1929 occurred because of the demand insufficiency and that the escape from the crisis would be through the state intervention (public spending) and in this regard through the budget deficits. However, as a result of increase in public spending, if there occurs to be a domestic demand pressure, the budget deficits cause inflation (Doğru, 2014). According to the founder of the monetarist economy Milton Friedman (1963), "the inflation is

7The inflation of Consumer Price Index was double-digited, $10.1 \%$ in 2008 and $10.4 \%$ in 2011. 
always a monetary matter everywhere. In every country where inflation is high for a long time, the growth of the money supply is high" (Mishkin, 1984).As can be understood from these expressions of Friedman, in the monetarist approach, as long as the fact that "the fiscal policy creates an impact of the monetary policy" is prevented, fiscal policy control is not necessary to ensure price stability. On the contrary, if the budget deficit is closed through monetization, there will be stimulant impact of monetary expansion on inflation. That is why the only aim of the central bank is to ensure the price stability and to control the quantity of money without concession within the framework of this aim. The control of the money passes through "monetary policy accords to rule", so to say, increasing the money supply in relation to the degree of economic growth. Uncompromising attitude and independency of the central bank will force the fiscal authority to apply a tight fiscal policy.

In neoclassical approach - having its roots based on monetarism and diverging significantly from Keynesian approach by accepting rational expectations rather those adaptive expectations - there is no reached consensus over the views on the budget deficit and inflation. For example, Robert Barro puts forward that among the indicators of total demand, there is also the fiscal policy and that the fiscal policy remains the least important as an indicator among these indicators. He explains that the budget deficits do not have a crucial impact on total demand and therefore on the price determination within the framework of Ricardo's Equation (Barro, 1974, 1989). Even though they are in the neoclassical school, another completely differentiated analysis was written by Sargent and Wallace (1981) named "Some Unpleasant Monetarist Arithmetic" and it found itself an important place in the economics literature. The article is a rejection of monetarist acceptance of "inflation is a monetarist phenomenon". According to Sargent and Wallace, in an environment where the fiscal deficits have continuity, it not possible to hold inflation low by making debts in the long term on one side and by applying tight monetary policy on the other. The process collapses finally and causes high inflation. There are three basic assumptions in Sargent and Wallace's analysis. The first one is the real interest rates of the public debts is higher than the economic growth. The second one is that the central bank had to gain revenue (senior age) by issuing money. The last assumption is that the central bank submits itself under the fiscal pressure. However, the first assumption is quite important. Because if the real interest rate is higher than the growth rate, debt stock/GDP rate will increase gradually and debts will be unsustainable. Unsustainable public debt will cause the monetary authority to create new monetary demand and therefore this will put the monetary base growth rate and inflation in an uncontrollable circumstance (Sargent \& Wallace, 1981).

In brief, according to Sargent and Wallace, financing the budget deficits in long term by incurring liabilities, will cause a more inflationist result compared to printing money in case where the opportunity to incur debts is eliminated. In other words, avoiding monetary financing causes more inflation in the long term. As the monetarists consider the monetization as the reason of inflation, this fact is called the "Unpleasant Monetarist Arithmetic". After Sargent and Wallace's article which opened new horizons, financial instabilities became the center of all the theoretical models which explain persistent inflation. In developing countries where there is a low level of activity to collect taxes, where there is political instability and where the access to foreign debts are limited, the approaches which took the fiscal-based theories of inflation as a basis, came into prominence. To sum up, this highly important article of Sargent and Wallace formed the intellectual basis of "Fiscal Theory of the Price Level (FTPL)" or shortly "Fiscal Approach" (Catao \& Terrones, 2001). FTPL approach rejects the monetarist approach in two important ways. Firstly, under some assumptions, what determines the inflation is not the quantity of money; it is rather the budget deficits and the public debts caused by these deficits. Secondly, in such a case the monetary policy and independency of the central bank would not be enough for the price stability. Appropriate fiscal policy must also be applied (Uygur, 2003).

According to FTPL approach, the budget deficit must be eliminated through an increase in the quantity of money in order prices to increase. If there are continuous budget deficits in an economy, the monetary policy is under pressure of these deficits and therefore of the fiscal policy (fiscal dominancy). In order for the public budget deficits not to exert an inflationist pressure, eliminitating these deficits through internal debt rather than monetization will cause the real interests to increase and create a status where the payment of these debts are made through incurring new debts. As a result of such a development, the interest burden increases to a considerable extent, the government have to head for monetization. The inflation which occurred at that point is comparatively higher (Uygur, 2001). Furthermore, in fiscal approach, the real interests which 
increase in relation to the increasing public debt, provide high real incomes to people of middle and high income people and /or institutions who lead towards for the government securities. These high real incomes cause both deterioration of the income distribution on one side and an extra pressure on the inflation by increasing consumption on the other side. The causality relationship of the fiscal approach from budget balance to the inflation can also cause an effect from inflation to the budget balance by creating a feedback effect. According to Dornbusch, Sturzeneggerand Wolf (1990), inflation affects the share of the budget deficit in gross domestic product by several mechanisms. The first effect is the Olivera-Tanzi Effect. Inflation causes the real tax incomes depreciate and the tax collection declines. As the inflation is high, so the real loss which will occur in the public's tax income will be relatively high. The second effect is that the high inflation causes unwillingness to pay taxes. This will create a decreasing effect on the public income. The third effect is the real value of the public debt stock may depreciate in a high inflationary environment. However, as the "Risk Premium" increases owing to the high inflation so the payments of the real interest debts increase accordingly. This is an additional burden over the budget (Catao and Terrones, 2001). Stated in the theoretical studies, there is a bidirectional relation between the budget deficit and inflation. Not only the budget deficit causes an inflationary pressure owing to the monetization and negative expectations, but also the high inflation has a feedback effect increasing the budget deficit.

\section{Literature Review}

The Dynamic Relations between the Inflation and the Public Budget Balance: There are several theoretical and empirical studies made on the emergence and the reasons of high and persistent inflation in the Turkish economy. Generally, among the elements feeding the inflation and the inflationist processes, the following can be enumerated; high public saving deficits, monetization of these deficits, high expectations of inflation, political instabilities, increases in import input prices, increases in oil prices. Among these possible reasons, some of them have high correlation with each other, whereas some other can only have limited effect for specific periods (Kibritçioğlu, 2004). According to the article of Kibritçioğlu (2004), there are several macro-economic variables affecting the emergence of high and persistent inflation. After a while, the interaction of these variables with inflation and the powerful feedback effects which emerged as a result of this case, make it hard to define the main effects. So, defining the causality relationship between the inflation, budget deficits and money supply is not easy in that sense. ${ }^{8}$ In addition to this, in the empirical studies which were carried out especially for Turkey, the fact the chosen sample periods are different, that the econometric methods applied are differentiated and that the chosen variables differ even though same periods and same econometric methods are used, change the found results completely. Hence, in the empirical studies made for the Turkish economy which we summarize below (for the period of 1948-2009); all the possible causality relationships are revealed. However, the dominant result is that the budget deficits feed the inflation.

According to us, the greatest reason behind the fact that different results are found within the estimated relations between the inflation and other macroeconomic variables is the sample period. These differences can be grouped under two headings. The first one is the start of the sample period can be in the periods, in which these two variables are highly deteriorated or in which the feedback effects occurred in a powerful manner. In that case, the variables which include the deterioration effects in the whole sample period are used. Secondly, the last periods of the used sample period might contain the periods which these two variables are in the levels that can still constitute a problem in terms of macroeconomics. So, it might not be possible to discover the relation in question. In brief, the chosen sample period may cause different results to emerge in measuring the power of the relation between variables and the causality relationship. As a result of all these reasons, the time period of the econometric study in this article is determined as 1975-2014. Because in the start and the endears of the chosen period, the inflation rates are one-digitedand the ratio of

\footnotetext{
8 "Economic theory postulates a clear causal connection between fiscal deficits and inflation in the long-run. However, this relation ship is not easily detectable in the data. One reason is the complex short-run dynamics of high inflation processes; as stressed by Calvo\&Vegh (1999) in their recent survey of the literature, once inflation rises to double-or triple-digit levels, strong feed back effects between the main macro variables make it very hard to identify the ultimate culprit(s)" (Catao\&Terrones, 2001: 15).
} 
budget deficit/GDP is about 1\%. Now, some of the important empirical studies for the Turkish economy will be summarized.

The dominant view on the inflationist process was mainly that the criminal was the fiscal instabilities and the monetization. However, the academic studies in recent periods show that the inflation has an inertial property and that the relation between budget deficits and inflation are statistically significant even in the periods in which monetization is excluded. In this context, the inertial nature of the inflation in Turkey is emphasized firstly in the monetary program announced during the signature of the $17^{\text {th }}$ stand-by agreement with International Monetary Fund in the December of 1999. In the second half of the 1980s, direct monetization rate (short term advances used by the Treasury from the Central Bank) which corresponds to $1.5 \%$ of the gross national product, increased to $3 \%$ in 1993. The monetization rate decreased in between 1994-1997. Finally, owing to an agreement between the Treasury and the Central Bank, Treasury ended using short term advances from the Central Bank. However, even though direct monetization was cut off, there was no tendency of inflation to fall down in that period. Shortly, in the roots of the inflationist process, the budget deficits are found. Eliminating the budget financing (open finance method), does not end the relation between the budget deficit and the inflation (TÜSİAD, 2002).

Altıntaş, Çetintaş \& Taban (2008) obtained a result which is totally on the contrary to what TUSIAD had obtained. Altıntaş, Çetintaş\&Taban analyzed the relation between budget deficit, monetary expansion and inflation in period which comprised the period of 1992:01 and 2006:12. According to the ARDL model which was used in the study, the monetary expansion has a positive and significant effect on the inflation in both short term and long term (except specific terms). On the other hand, it is observed that the budget deficit does not have a significant relation with the inflation in the short and long term. The findings have the feature of supporting the monetarist view (Altıntaş, Çetintaş \& Taban, 2008). In the study by Akçay, Alper \& Özmucur (1996), in which they used yearly dates and which comprises the period of 1948-1994, budget deficit/GNP, percentage change of currency in circulation and GNP deflator based inflation were used as variables. In the study, carried out with the yearly data and under the assumption of long term monetary neutrality ${ }^{9}$, a high correlation from the budget deficit to inflation was found. In another study carried out by Alper \& Üçer (1998), the monthly data were used for the period of 1985/I-1997/9. The chosen variables were Consumer Price Index/CPI, Producer Price Index/PPI, M1, M2, M2Y and foreign currency basket (U.S. Dollarandthe Deutsche Mark). The authors reached the conclusion that the relation between the fiscal imbalances and the inflation was weaker than it was thought and that the reason of inflation in Turkey is the "inflation" itself. Özgün (2000) made a study for the period of 1950-1998 by using the annual data of budget deficit / GDP, percentage change of currency in circulation and the inflation rates. At the end of the cointegration test made by using the annual data, it was observed that there was a long term linear positive correlation between the budget deficit, money in circulation and the inflation and that there was also a bi-directional causality relationship between the budget deficits and the inflation.

Supportive results for Özgün's (2000) findings were obtained by Çetintaş (2005). In his study, Çetintaş uses the period of 1985-2003 and analyzes the relation between inflation and budget deficit by using bivariate and multivariate models. Both the findings of the two models used by Çetin point out that there is a bi-directional causality relationship between the budget deficits and the inflation. In order to decrease the inflation in Turkey, the budget deficits must absolutely be decreased (Altıntaş, Çetintaş \& Taban, 2008). In the study of Oktayer (2010), the relation between the budget deficit and the money supply in Turkey was tried to be analyzed by using quarterly data in the period of 1987-2009. The findings suggest that there is a direct impact of budget deficit on inflation. In the study of Günaydın (2004) made by using JohansenJuseliusCointegration Test with the data of budget/deficit/GNP, (Whole Sale Price Index/WPI AND M1 for the period of 1971-2002, it was found out that the budget deficits have direct impact on inflation both in the short term and in the long term. As can be understood from the above paragraphs, it is not very clear what is the main responsible/responsible in the interaction dynamic between the budget deficit, inflation and money supply in the Turkish economy. In the studies made for Turkey just like those made even for other

\footnotetext{
${ }^{9}$ Money Neutrality is the idea that a change in the stock of Money affects only nominal variables in the economy such as prices, wages, and exchange rates, with no effect on real variables, like employment, real GDP, and real consumption.
} 
countries $^{10}$, fiscal balance is not as an explanatory variable for the inflation. As an example; Togan, 1987; Öniş \& Özmucur, 1990; Darrat, 1997 and Akyürek, 1999 studies can be given (Kibritçioğlu, 2002).

\section{Data Analysis and Results}

Data Set and the Econometric Model: In this part, questioning the long term relationship basically between the inflation and some macroeconomic variables and determining the causality relationship were aimed. The variables used in this study for this purpose are the inflation rates (\%), interest payments/budget expenditures (\%), budget deficit/GDP (\%), money in circulation (Million TL) and USD/TL exchange rate. The annual data of 1975-2014 period were used. Data sources regarding the variables were based on Republic of Turkey Ministry of Development (Economic and Social Indicators), Istanbul Chamber of Commerce and Central Bank of The Republic of Turkey (Electronic Data Delivery System). The inflation is based on Wholesale Price Index (WPI) $(1963=100)$ and is calculated by us. The money in circulation and the foreign exchange rates were used in the anaylsis after the logarithmic transformations were carried out. In order to test the stationarity of the series, Perron (1997) test was used and the structural break was taken into consideration. The test results are summarized in Table 1.

Table 1: Unit Root Tests with Structural Break

\begin{tabular}{lllllll}
\hline & Level & \multicolumn{5}{l}{ First Difference } \\
\hline Series & Test Statistics & $\begin{array}{l}\text { LagLe } \\
\text { nght }\end{array}$ & $\begin{array}{l}\text { Break } \\
\text { Date }\end{array}$ & Test Statistics & $\begin{array}{l}\text { Lag } \\
\text { Length }\end{array}$ & $\begin{array}{l}\text { Break } \\
\text { Date }\end{array}$ \\
\hline $\begin{array}{l}\text { Inflation } \\
\text { Interest }\end{array}$ & $-4.3223[0.1995]$ & 0 & 2002 & $-6.5185[<0.01]$ & 1 & 1994 \\
$\begin{array}{l}\text { Paym./Budget } \\
\text { Expenditure) }\end{array}$ & $-2.9101[0.9355]$ & 0 & 2004 & $-9.0828[<0.01]$ & 0 & 2001 \\
$\begin{array}{l}\text { (Budget Deficits/GDP) } \\
\text { Money in Circulation }\end{array}$ & $-3.7565[0.5280]$ & 0 & 2004 & $-6.6604[<0.01]$ & 0 & 2005 \\
Exchange Rate & $-4.4303[0.2218]$ & 1 & 2002 & $-6.6102[<0.01]$ & 0 & 2009 \\
\hline
\end{tabular}

Notes: Perron (1997) was performed for unit root test with structural break. Vogelsang (1993) asymptotic one-sided $p$-values are used and provided in square brackets. Trend specification is trend and intercept, break specification is intercept only, break type is an innovational outlier. The null is "series is has a unit root with a structural break".

Unit root test results depict that all series are stationary in first differences. In that step, in order to determine the direction of the relation between the variables causality tests will be carried out. In the causality tests, it is researched whether a change in the variable affect the other variable and whether it cause any change in it. Approaches used for the causality purposes differentiate in accordance with the time series of the variables in question. These series show differences according to whether they are in integrated order and they are cointegrated. As all the series used in this research are I(1), it is necessary to carry out the cointegration test before the causality tests. This problem will be tried to be answered by the Johansen $(1991,1995)$ cointegration test. Johansen method is related to basics of VAR method and it uses the test of most probability rate. The beginning step of the Johansen cointegration analysis is estimating the unrestricted $\operatorname{VAR}(p)$ model and determining the lag length. For this aim, VAR model is estimated and lag length are summarized in Table 2.

10Romer (1993), Lane (1995), Carnpillo\&Miron (1996) and Click (1998) studies can be given as examples to this (Catao\&Terrones, 2001: 4). 
Table 2: The Determination of Time Lag Lengths of the VAR Model

\begin{tabular}{llllll}
\hline Lags & LR & FPE & AIC & SCI & HQ \\
\hline 0 & NA & 0.211184 & 6.953815 & 7.514294 & 7.133117 \\
1 & 80.93326 & 0.011651 & 4.034978 & 5.015816 & 4.348757 \\
2 & $\mathbf{2 2 . 7 0 8 7}^{*}$ & 0.007193 & 3.499542 & 4.900740 & 3.947797 \\
3 & 15.08601 & 0.005991 & 3.212130 & 5.033686 & 3.794861 \\
4 & 13.85350 & 0.004882 & 2.822594 & 5.064510 & 3.539803 \\
5 & 15.36600 & 0.003009 & 2.025685 & 4.687960 & 2.877370 \\
6 & 13.61955 & $\mathbf{0 . 0 0 1 7 4}^{*}$ & $\mathbf{0 . 9 2 3 2 4}^{*}$ & $\mathbf{4 . 0 0 5 8 7}^{*}$ & $\mathbf{1 . 9 0 9 4 0}^{*}$ \\
7 & 3.114641 & 0.004429 & 0.930313 & 4.403307 & 2.020951
\end{tabular}

${ }^{*}$ The bold ones indicate the optimum lag length for the relevant criteria. LR: Likelihood Ratio Test Statistics,
FPE: Final Prediction Error, AIC: Akaike Information Criteria, SIC: Schwarz Information Criteria, HQ: Hannan-
Quinn Criteria.

Evaluating the criteria in Table 2, it was found out that the optiumum lag is 6 and in this lag and the stability conditions of the model in this lag were achieved. According to this it was found out that the model is in the structure of VAR(6) ${ }^{11}$. Between the variables, Johansen cointegration test will be carried out to test the long term relation. In order to determine the rank of long term information matrice or cointegre vector number, two methods are proposed by the Johansen (1991 and 1995): Trace and maximum eigenvalue statistics.

Table 3: JohansenCointegration Tests

\begin{tabular}{|c|c|c|c|c|}
\hline \multirow{2}{*}{$\mathbf{H}_{\mathbf{0}}$} & \multirow{2}{*}{$\begin{array}{l}\text { Trace } \\
\text { Statistic }\end{array}$} & \multirow{2}{*}{$\begin{array}{l}\text { Maximum } \\
\text { Eigenvalue }\end{array}$} & \multicolumn{2}{|c|}{ Critical Values (.05) } \\
\hline & & & Trace & $\begin{array}{l}\text { Max- } \\
\text { Eigenvalue }\end{array}$ \\
\hline$r=0$ & $27.77183^{*}$ & $20.51685^{*}$ & 24.27596 & 17.79730 \\
\hline$r \leq 1$ & 7.254979 & 5.369599 & 12.32090 & 11.22480 \\
\hline$r \leq 2$ & 1.885381 & 1.885381 & 4.129906 & 4.129906 \\
\hline
\end{tabular}

Note: * denotes significant at .05 significance level. Cointegration spesification is intercept and trend in CE, no intercept in VAR model.

When the statistics of Trace and maximum eigenvalue are compared with Osterwald-Lenum (1992) critical values, it is observed that the first hypothesis is rejected at the .05 significant level. Therefore according to both models, there is statistically significant 1 cointegrated vector. According to this, there is a long term and significant relation between the inflation and the components (interest payments/budget spendings and budget balance/GDP) for the period of 1975-2014. Table 4 shows the results of the Johansen cointegration analysis between the inflation and other variables.

Table 4: Results of Johansen Cointegration Analysis with Normalized Cointegrating Coefficients

\begin{tabular}{lcccc}
\hline $\begin{array}{l}\text { Sample } \\
\text { Period }\end{array}$ & Intercept & $\begin{array}{l}\text { (Interest } \\
\text { Payments/Budget } \\
\text { Expenditures) } t \text {-1 }\end{array}$ & $\begin{array}{l}\text { l(Budget } \\
\text { Deficits/GDP) } t \text { - } 1\end{array}$ & $\begin{array}{c}\text { Linear } \\
\text { Trend }\end{array}$ \\
\hline $1975-2014$ & -19.9682 & 0.7309 & 0.8558 & 0.8391 \\
& $(0.3463)$ & $(0.2802)$ & $(0.1313)$ \\
& {$[2.1102]$} & {$[3.0545]$} & {$[6.3890]$} \\
\hline
\end{tabular}

Notes: 1. Inflation rate is the dependent variable. 2. The numbers in paranthesis are standart errors, $t$ statistics are in brackets. Lag lenght is 5. 3. In order to signify the economic crisis in the Turkish Economy the

\footnotetext{
11 In the residual of VAR model, according to Breusch-Godfrey LM test, there is no autocorrelation for 12 lags. According to residuals of White test, there is no heteroscedesticity and according to Jarque-Bera test, components have a normal distribution one by one and jointly.
} 
dummy varible is used which is 1 in 2001-2002 and 2008-2009, money in circulation and USD/TL exchange rate are employed as exogeneus variables in the model.

Table 5: Granger Causality Results Based on VECM

\begin{tabular}{llll}
\hline Dependent Variables & \multicolumn{2}{l}{ Wald Statistics } & \\
& $\Delta$ Iflation & $\begin{array}{l}\Delta \text { (Interest } \\
\text { Paym./Budget } \\
\text { Expenditures) }\end{array}$ & $\begin{array}{l}\Delta \text { (Budget } \\
\text { Deficits/GDP) }\end{array}$ \\
\hline$\Delta$ Inflation & - & $\begin{array}{l}135.5633^{*} \\
{[0.0000]}\end{array}$ & $\begin{array}{l}149.5337^{*} \\
{[0.0000]}\end{array}$ \\
& & & 5.7406 \\
$\Delta$ (Interest & $18.5425^{*}$ & - & {$[0.3323]$} \\
Paym./Budget & {$[0.0023]$} & & \\
Expenditures) & & & - \\
$\Delta$ (Budget Deficits/GDP) & 3.2927 & $16.0975^{*}$ & \\
& {$[0.6550]$} & {$[0.0066]$} & \\
\hline
\end{tabular}

Note: ${ }^{*}$ indicates the test statisticsaresignificant at the $1 \%$ level.

All the paremeters estimated are statistically significant. The estimates of the cointegration, while the other variables remain constant, show that when the share of interest payments in the budget spending increase by 1 point, inflation rate increases by 0.73 point; whereas when the share of budget deficit in the GDP increases by 1 point, the inflation rate increases by 0.86 point. Long-term estimate results suggest that inflation is more affected by the share of the GDP in budget deficit.In error correction equations, the error correction term is significant only in the inflation equation. ${ }^{12}$ This term signifies the tendency from short term imbalances to long term balance. According to this, it can be said that the difference between the balance values is closed by 0.0866 point every year. The cointegrated relation determined between the variables gives us valuable information on how to carry out the causality test. The causality test will be carried out by using VECM. The VECM based Granger Causality results are given in Table 5 . The findings in the Table 5 gives us information on the short term causality between the variables. According to this, there is causality from interest payments/budget expenditures and budget deficits/GDP to inflation and from inflation to interest payments/budget expenditures, from interest payments/budget expenditures to budget deficits/GDP. The findings show that there is feedback between the inflation and interest payments/budget expenditure. The causal channels can be summarized as below:

\section{Figure 1: Granger Causality Test Flow Chart}

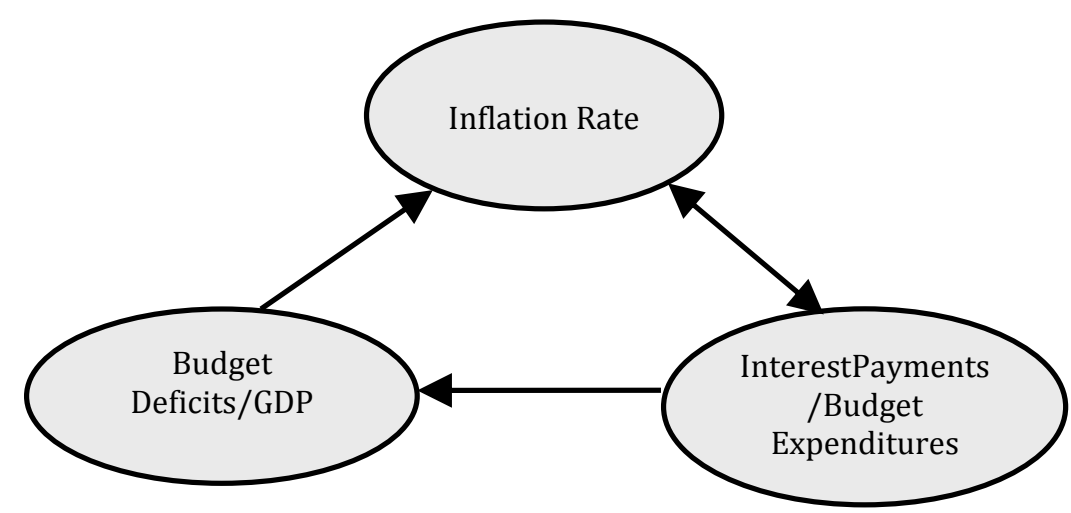

Figure1 refers following: High inflation leads to increase of the share of the interest rate within the budget due to risk premium and this also conduces to an increase in budget deficit. On the other side, the growing

${ }^{12} \mathrm{ECT}_{t-1}$ for the terms inflation, interest payments/budget spending andbudget balance/GDP equations are estimated respectively $-0.0866(0.0124)[-6.9546],-0.5901(0.6052)[-0.9748]$ and $-0.2663(0.3084)[-0.86373]$. The numbers in paranthesis are standart errors, $t$-statistics are in brackets. 
budget deficit, by creating negative expectations, is the source of the high and chronic inflation rates. Accordingly, a vicious cycle develops between inflation rates and budget deficit. When Figure 1 is examined, this dynamic process and developing vicious cycle are clearly observed. As emphasized throughout the article, we believe that the inflation rate is the most significant variable initiating this vicious cycle.

\section{Conclusion and General Evaluations}

The average inflation rate of the Turkish economy between 1970-1975 is 17\%. Especially after 1977 with the political turmoil which Turkey faced and with the impact of the second oil crisis, the inflation rates increased to $53 \%$ in 1978 and 90\%in 1980. Remaining between $27 \%$ and $46 \%$ between 1981-1987, the inflation rate showed again tendency to increase after 1988 and showed a persistent and high structure until 2004. The average of inflation rate of 1988-2003 is 68\%. Although there had been all these negative developments in inflation, the budget deficits/GDP ratio which we take as a reference in the fiscal balance, remained below $3 \%{ }^{13}$ which is the Maastricht Criteria and was around $2 \%$. So, these data figure out the following: Leaving aside the empirical studies, the budget deficit which was about $2 \%$ in average within the period of 1975-1990 cannot be the reason for the inflation which was 30\%-65\% in average in the same period. In that period, there cannot be a bilateral relation, too. The relation between these two variables is shown in Figure 2 . We can extend the analysis in the following way: Especially after 1987, the tendency of the inflation to increase and to be persistent caused the nominal and real interest rates of Government Domestic Borrowing Securities (GDBS) to increase owing to the increased risk premiums. When Figure 3 is analyzed, it is clearly observed that as the inflation is high, so the nominal and real interest rates of GDBS are high. ${ }^{14}$ Increasing nominal and real interest rates caused an increase in the cost of public borrowing on one side, whereas an increase in the interest burden in the GDP and budget spending on the other. In brief, high inflation causes high interests; therefore this causes the interest burden in the budget spending to increase and the budget deficit to grow. So, there is a causality relation from the rate of inflation to the budget deficit. The Figure 3 shows the relation between Interest Payments/Budget Expenditures and Budget Deficit/GDP.

Figure 2: Inflation Rates (WPI) and Budget Deficit/GDP (1975-1990)

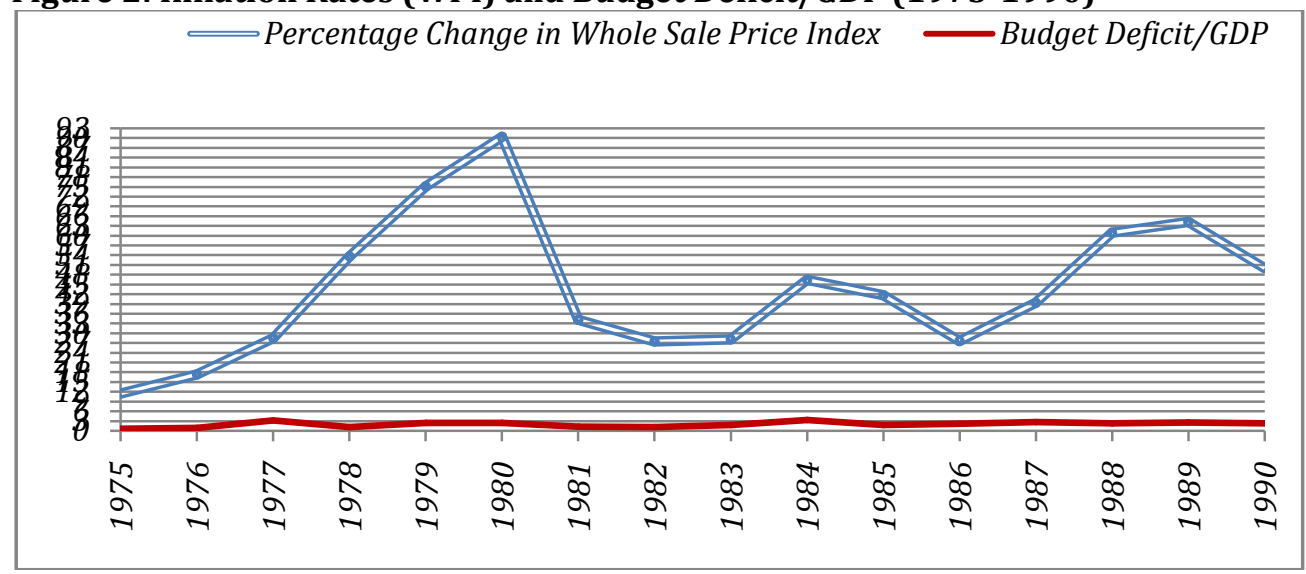

Source:http://www.kalkinma.gov.tr/Pages/EkonomikSosyalGostergeler.aspx

${ }^{13}$ Except for two years, it was 3.2\% in 1977 and 3.3\% in 1984 .

${ }^{14}$ When Figure 3 is analyzed, in the period in which the inflation is high, it can be observed that the margin between the nominal interests and inflation increases. That means; because of the increasing risk premiums, the real interest increase. Similiarly, the decrease of inflation to one digited rate after 2004 narrowed considerably the real interest margin. 
Figure 3: Average Compound Nominal Interest Rates of GDBS and Inflation Rates (WPI) (1989-2014)

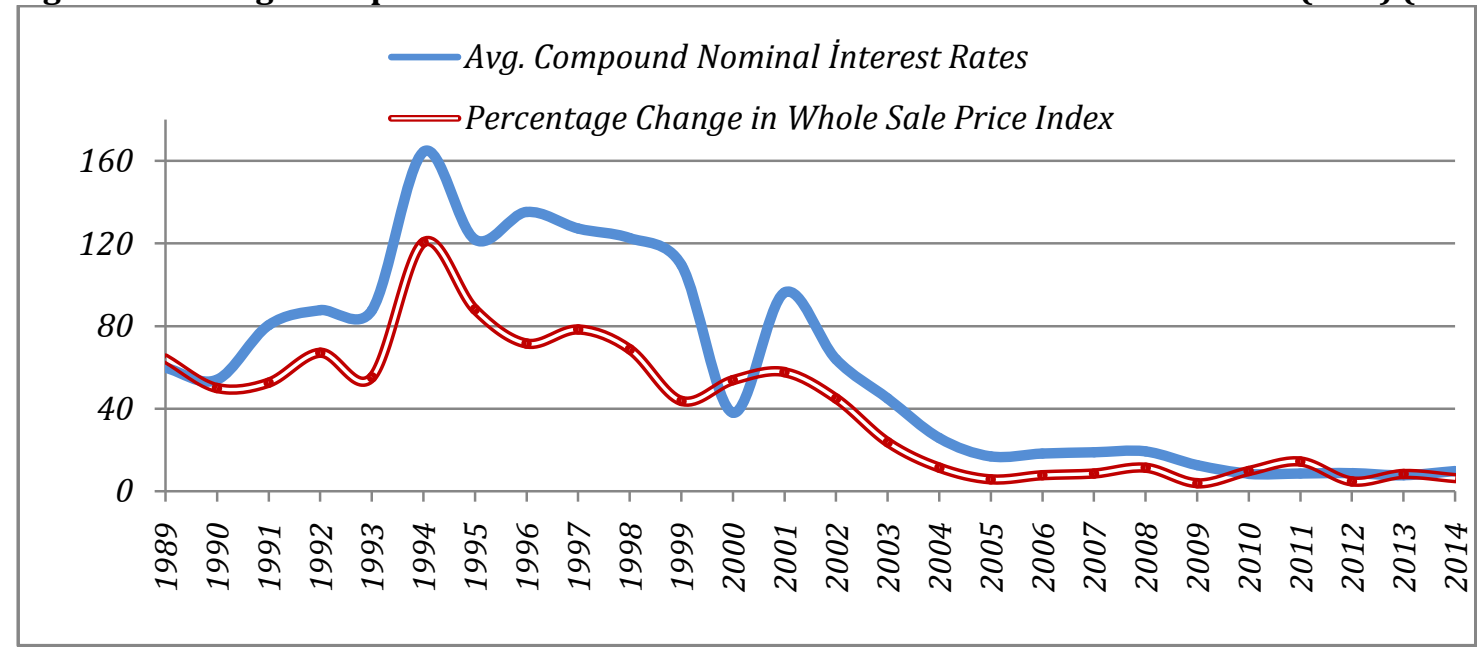

Source: http://www.kalkinma.gov.tr/Pages/EkonomikSosyalGostergeler.aspx

Figure 4: Budget Deficit/GDP and Interest Repayments/Budget Expenditures (1975-2014)

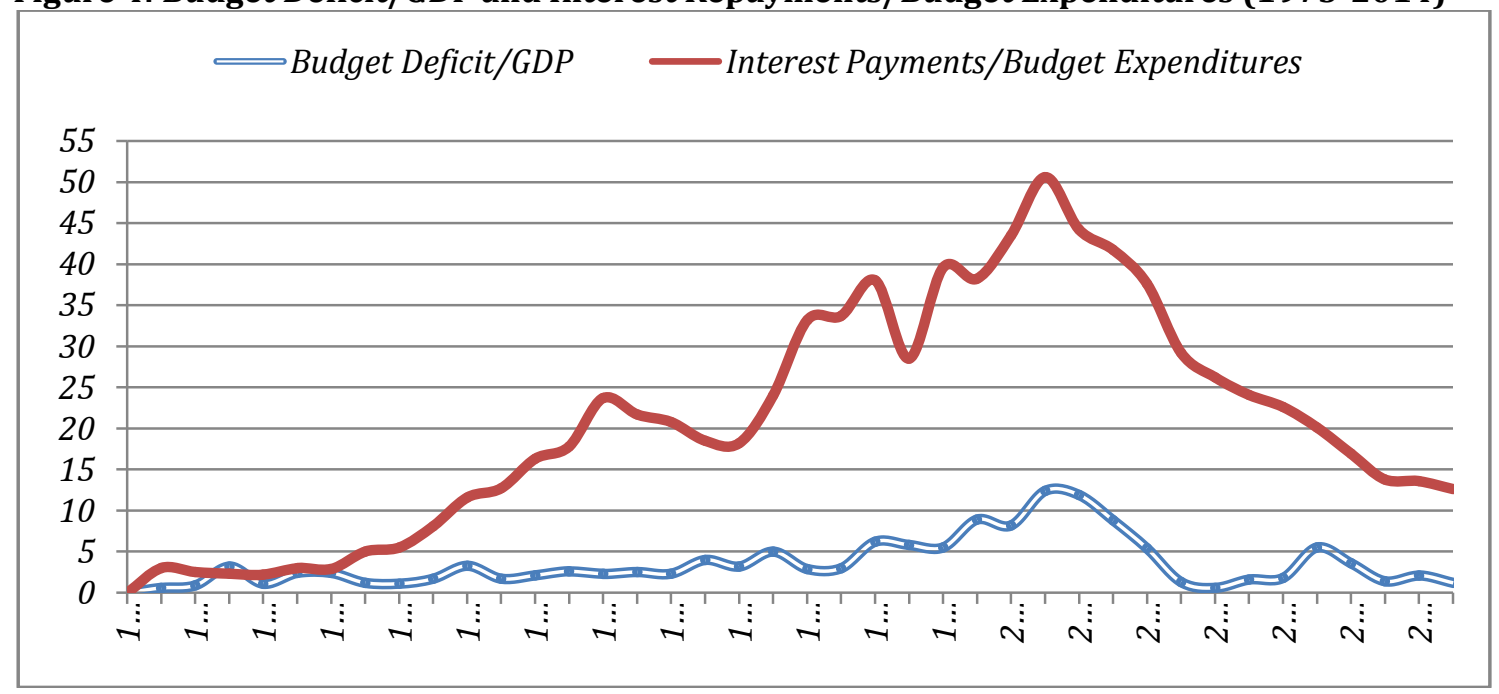

Source: http://www.kalkinma.gov.tr/Pages/EkonomikSosyalGostergeler.aspx

It must be underlined that continuously increasing budget deficits throughout the period of 1991-2001 caused the shortage of maturity dates of Government Domestic Borrowing Securities (GDBS) owing to the increase in risk premiums on one side and the increase of internal debt stock considerably on the other side. All these deteriorations which are depicted in the macroeconomic indicators caused a powerful pressure and inertia back in inflation. In addition to this, continuously increasing interest payment shares in the budget caused a decrease in current expenditures and especially in investment expenditures. This supported indirectly the increase in inflation. In Figure 5, it can dramatically be seen how the Crowding Out phenomenon gained strength until 1990s due to increasing interest rates. 
Figure 5: Interest Repayments/Investment Expenditures (1975-2014)

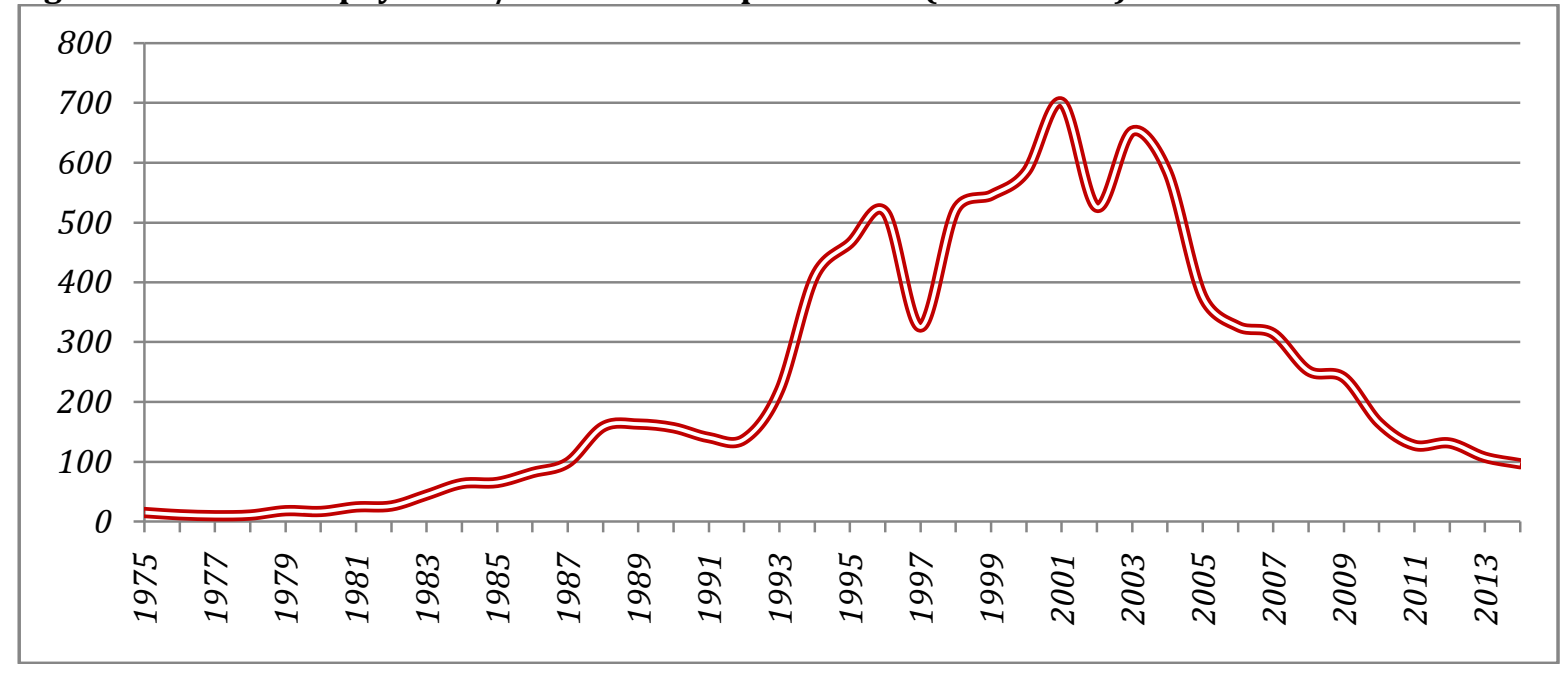

Source: http://www.kalkinma.gov.tr/Pages/EkonomikSosyalGostergeler.aspx

To sum up; a strong and bilateral relation between the inflation and the budget deficit is observed in the 1990s. This vicious circle which supports the fiscal approach (FTPL), come into prominence as one of the most important factors explaining the relationship between the inflation and budget deficit in the Turkish economy of 1990s. One of the most important developments of the Turkish economy in 2000s is the financial crisis of February 2001 which is one of the deepest financial crisis of the republican history. In 2001, the Turkish economy shrank by $-9.5 \%$ and the budget deficit/GDP ratio reached $12.5 \%$. Interest payments/budget expenditures ratio exceeded over 50\%. EU-Defined General Government Debt Stock/GDP reached $78 \%$. These ratios are the highest ratios observed in the republican history. Following the February 2001 crisis, "Program for Transition to a Strong Economy - PTSE" was announced on 15 April 2001, a new economic program was started in Turkey. Owing to the tight monetary and fiscal policy which started with the program, double digested, high and persistent inflation rates which started in 1970s decreased to $9.4 \%$ in 2004. Following the decrease of inflation to one digested numbers in 2004, the process which was passed through in 1990s was reversed. The decrease in the inflation rates caused a decrease in nominal and real interest rates of the Government Domestic Borrowing Securities and in the share of interest burden in the budget ${ }^{15}$. On one hand, the tight fiscal and monetary policy and on the other hand the decreasing interests decreased considerably Turkey's budget deficit in 2000s. For example, in 2005, the budget defect/GDP ratio which is a Maastricht Criteria declined to 1.3\%. Similarly, EU-Defined General Government Debt Stock/GDP ratio decreased to $52.7 \%$ in 2005 and $40 \%$ in 2007. In 2014, budget deficit/GDP ratio is $-1.2 \%$ and EUDefined General Government Debt Stock/GDP ratio is 34.1\%. These values are far below the Maastricht Criteria.

According to the authors of the article, these positive developments which the Turkish economy have passed through in 2000s occurred as a result of the reverse process to the relation between inflation and budget deficit which was analyzed in 1990s. This relation emerged as a result of the reverse action of the bidirectional vicious cycle. We think that the most important factor which started this process is the rapid decrease achieved in inflation rates. Finally we would like to indicate the following: Turkish economy faced two great crises in 1994 and in 2001 within the period of 1980-2001 which are the lost years in economic terms. Unsustainable budget deficits and current account deficits are in the basis of these crises. Especially the most important variable which has the biggest share in deterioration of the public budget balance and which has indirectly affected the macroeconomic variables negatively is the high and persistent inflation which has continued for 30 years.

15 While the Interest Payments/Budget Expenditures rate was 50,6 \% in 2001, it declined to 29.2\% in 2005 and $22.6 \%$ in 2008, 16.9\% in 2010 and $11.4 \%$ in 2014 (www.kalkinma.gov.tr). 


\section{References}

Akçay, O., Cevdet, C., Alper \& Özmucur, S. (1996). Budget Deficit, Money Supply and Inflation: Evidence from Low and High Frequency Data for Turkey. Bogazici University Research Papers, No: 96/12, 1-12.

Aktan, C. (2002). http://www.canaktan.org/ekonomi/kamu_maliyesi/maliye-iflas/lord-keynes.htm (in Turkish)

Akyürek, C. (1999). An Empirical Analysis of Post-Liberalization Inflation in Turkey. YapıKredi Economic Review, 10(2), 31-53.

Alper, C. E. \& Üçer M. (1998). Some Observations on Turkish Inflation: A Random Walk down the Past Decade. Bogazici Journal: Review of Social, Economic and Administrative Studies, 12(1), 7-38.

Altıntaş, H., Çetintaş, H. \& Taban, S. (2008). Econometric Analysis of the Relationship between Budget Deficit, Monetary Growth and Inflation in Turkey: 1992-2006. Anadolu University Journal of Social Sciences, 8(2), 185-208.

Barro, J. R. (1974). Are Government Bonds Net Wealth? Journal of Political Economy, 59(2), 93-116.

Barro, J. R. (1989). Interest Rate Targeting. Journal of Monetary Economics, 23, 3-30.

Carnpillo, M. \& Miron, J. A. (1996). Why Does Inflation Differ Across Countries? NBER Working Paper No. $5540,1-38$.

Catao, L. \& Terrones, M. (2001). Fiscal Deficits and Inflation: A New Look at the Emerging Market Evidence, IMF Working Papers, WP/01/74, 1-31.

Click, R. (1998). Seigniorage in a Cross-Section of Countries. Journal of Money, Credit and Banking, 30, 154163.

Çakman, K. \& Çakmak, U. (2003). An Analysis of the Crisis-Dynamics in the Post-1989 Turkish Economy. IktisatissletmeveFinans, 213, 29-50.

Çetintas, H. (2005). Turkiye' de Bütçe Açıkları Enflasyonun Nedenimidir? (in Turkish). ÍktisatíşletmeveFinans, $20(229), 115-31$.

Doğru, B. (2014). Is There a Causality Relationshıp Between Budget Deficit and Inflation Ratio During High Inflation Period? Case of Turkey Between 1978 and 2002, EskișehirOsmangazi University. Journal of Economics and Administrative Science, 9(1), 113- 129.

Darrat, A. F. (1997). Domestic and International Sources of Inflation in Some Muslim Countries: An Empirical Inquiry. The Middle East Business and Economic Review, 9(1), 14-24.

Dornbusch, R., Sturzenegger, F. \& Wolf, H. (1990). Extreme Inflation: Dynamics and Stabilization. Brookings Papers on Economic Activity, 2, 1-84.

Erçel, G. (2001). Konuşmalar (2000) (in Turkish), Central Bank of the Republic of Turkey (CBRT) Ankara, 1188.

Friedman, M. (1963). Inflation: Causes and Consequences, Bombay: Asia Publishing House Reprinted in Friedman, Dollars and Deficits, Englewood Cliffs, N.J.: F'rentice-Hall, 1968, p. 39.

Fisher, I. (1911). The Purchasing Power of Money, New York, MacMillan Ltd, 1963.

Günaydın, İ. (2004). Are Budget Deficit Inflationary? An Analysis For Turkey, DokuzEylul University. Journal of Graduate School of Social Sciences, 6(1), 158-181.

http://stats.oecd.org/

Johansen, S. (1991).Estimation and Hypothesis Testing of Cointegration Vectors in Gaussian Vector Autoregressive Models. Econometrica, 59, 1551-1580.

Johansen, S. (1995).Likelihood-based Inference in Cointegrated Vector Autoregressive Models, Oxford: Oxford University Press.

Kibritçioğlu, A. (2002). Causes of Inflation in Turkey: A Literature Survey with Special Reference to Theories of Inflation, in Kibritçioğlu, Aykut, Rıttenberg, Libby \&Selçuk, Faruk (Eds.), Inflation and Disinflation in-Turkey, Hampshire: Ashgate Publishing Limited, 43-76.

Kibritçioğlu, A. (2004). A Short Review of the Long History of Turkish High Inflation, http://econwpa.repec.org/eps/mac/papers/0404/0404003.pdf, 1-27.

Lane, P. (1995). Inflation in Open Economies. Journal of International Economics, 42, 327-347.

Mishkin, S. F. (1984). The Causes Of Inflation, NBER Working Paper, No. 1453, 1-28

Oktayer, A. (2010). Budget Deficits, Monetary Growth and Inflation Relationship in Turkey. MaliyeDergisi, $158,431-447$. 
Osterwald-Lenum, M. (1992). A Note with Quantiles of the Asymptotic Distribution of the Maximum Likelihood Cointegration Rank Test Statistics. Oxford Bulletin of Economics and Statistics, 54(3), 461472.

Özgün, B. D. (2000). An Empirical Approach to Fiscal Deficits and Inflation: Evidence From Turkey, The Undersecretariat of Treasury General Directorate of Economic Research Working Papers, 1-28.

Öniş, Z. \& Özmucur, S. (1990). Exchange Rates, Inflation and Money Supply in Turkey: Testing the Vicious Circle Hypothesis. Journal of Development Economics, 32(1), 133-54.

Perron, P. (1997). Further Evidence on Breaking Trend Functions in Macroeconomic Variables. Journal of Econometrics, 80(2), 355-385.

Romer, D. (1993). Openness and Inflation: Theory and Evidence. Quarterly Journal of Economics, 108, 869903.

Sargent, A., Thomas J. \& Wallace N. (1981). Some Unpleasant Monetarist Arithmetic. Federal Reserve Bank of Minneapolis Quarterly Review, 5(3), 1-17.

Togan, S. (1987). The Influence of Money and the Rate of Interest on the Rate of Inflation in a Financially Repressed Economy: The Case of Turkey. Applied Economics, 19(12), 1585-601.

Tokgöz, E. (1998). Türkiy eİ ktisadi Gelişme Tarihinin Ana Çizgileri (1923-1997), TürkiyeEkonomisiSektörelAnaliz (in Turkish), Ed: Ahmet Şahinöz, Turkish Economic Association, Turhan, Ankara, 3-41.

Türkkan, E. (1998). 1990 SonrasındaTürkiye'deSanayileşme, TürkiyeEkonomisiSektörelAnaliz (in Turkish), Ed: Ahmet Şahinöz. Turkish Economic Association, Ankara, 113-145.

TÜSİAD. (2002). Enflasy on ve Büyüme Dinamikleri: Gelişmekte Olan Ülke Deneyimleri Işığında Türkiye Analizi (in Turkish), No: TÜSİAD-T/2002-12/341, İstanbul, 1-125.

Uygur, E. (2001). Türkiye'deEnflasyon, TürkiyeEkonomisiSektörelAnaliz (in Turkish), Ed: Ahmet Şahinöz, Turkish Economic Association, Turhan, Ankara, 357-411.

Uygur, E. (2003). The Dynamics of Inflation and Stability. IktisatissletmeveFinans, 211, 50-67.

Vogelsang, J. T. (1993). Essays On Testing for Nonstationarities and Structural Change in Time Series Models, Unpublished Ph.D. Dissertation, Princeton University, Princeton, NJ.

Yılmaz, E. (2012). Gt veKamuBorçlanması̈̈zerineKeynes'inGenelTeorisiÜzerine (in Turkish), Ed: SelçukAkalın, Ahmet İncekara and GülsümAkalın, Kalkeon, İstanbul, 1-20.

www.ekonomi.gov.tr

www.hazine.gov.tr

www.kalkinma.gov.tr

www.tcmb.gov.tr

www.tuik.gov.tr 